\title{
Effect of winter pasture residuals' and grazing- off on subsequent milk production and pasture performance
}

\author{
D.A. CLARK, W. CARTER, B. WALSH, F.H. CLARKSON and C.D. WAUGH \\ Dairying Research Corporation, Private Bag 3123, Hamilton
}

\begin{abstract}
Concern at the effect of winter pasture residuals on pasture productivity led to the comparison of different wintering systems at the DRC No. 3 Dairy from May-December 1993. Three farmlets were designed to have $2000 \mathrm{~kg}$ DM/ha average farm cover at calving, but with pastures grazed to either 900,1400 or $1800 \mathrm{~kg}$ DM/ha at least once during the winter. A fourth farmlet was spelled from grazing from 25 May-4 July to give an average farm cover at calving of $2900 \mathrm{~kg}$ DM/ha. Pasture regrowth, composition and structure, milk yield, liveweight and reproductive performance were measured. A simulation model UDDER was used to generalise from the specific experimental results. Pasture regrowth in July-August was greater on the wintering-off treatment than those grazed during winter, but treatment differences in late spring were inconsistent. Wintering-off decreased ryegrass tiller and white clover growing point densities in August but differences had disappeared by November. Winter grazing treatment had no effect on any component of milk production from calving to late October. From late October until mid=December-milk-protein-and-milksolids_y i e l were less on the wintering-off treatment than the mean of the other three treatments $(0.62$ vs 0.68 $\mathrm{kg} / \mathrm{cow} /$ day) and (1.49 vs $1.59 \mathrm{~kg} / \mathrm{cow} /$ day), respectively. Grazing to different winter pasture residuals had no consistent effects on subsequent pasture productivity, composition or milk yield. Simulation showed that wintering-off can lead to increased milksolids production when average farm cover in September is predicted to fall below 1750 $\mathrm{kg} \mathrm{DM/ha.} \mathrm{Timing} \mathrm{and} \mathrm{amount} \mathrm{of} \mathrm{conservation}$ become critical after wintering-off if pasture quality and hence milk production are to be maintained in late spring.
\end{abstract}

Keywords: dairy cow, milksolids, milk yield, pasture regrowth, pasture residual, pasture structure

\section{Introduction}

Over the past 30 years New Zealand dairying has adopted high stocking rates associated with low per cow milk yield. This system relies on the establishment of long winter rotations to ration pasture at maintenance intake with little supplementary feeding and consequently low pasture residuals (Bryant \& Sheath 1987). Early calving has been used to complete a greater proportion of the lactation before the summer decline in perennial ryegrass growth rate and quality. Average farm cover at calving and in September are key factors in the success of highstocked systems. Pasture rationing slows the decline of average farm cover in the first 6 weeks of lactation. This system produces high milksolids/ha but results in underfeeding of cows, but has the potential to damage soil by pugging and may delay the onset of regrowth. Some commentators (e.g., Stakelum 1994) have suggested the use of more nitrogen fertiliser to produce better quality silage for improved winter nutrition. Wintering-off all or part of the herd for 4-6 weeks after drying-off is used as a means of increasing farm cover at calving (Robertson 1994).

Recent work in the Waikato (Chapman 1994) and Southland (Greenwood \& McNamara 1992) has shown the deleterious effect of intensive livestock farming on soil physical parameters. There is also concern at the loss of ryegrass plants and the perception that dairy pastures in the Waikato need to be frequently undersown. The $\mathrm{d}$ present experiment examined the issue of winter pasture residuals and the effect of average farm cover at calving using farmlet systems at Dairying Research Corporation (DRC), Hamilton, in the winter-spring of 1993.

\section{Methods}

\section{Site}

The DRC No. 3 Dairy farm at Ruakura, Hamilton was used for the experiment from 25 May-15 December 1993. Soil types were Te Rapa silty peat, Te Kowhai silty clay loam and Motumaoho silty peat. Average winter and spring rainfall are 340 and $294 \mathrm{~mm}$ respectively; rainfall during the trial period was 279 $\mathrm{mm}$ in winter and $199 \mathrm{~mm}$ in spring.

\section{Treatments}

The experiment used four herds stocked at 3.75 Friesian cows/ha with 24 cows per treatment. Blocks of several 0.4 ha paddocks randomly allocated to treatment gave 16 paddocks per treatment. Table 1 gives the experimental treatments. 
Table 1 Winter grazing management treatments.

\begin{tabular}{ccc}
\hline Treatment & Winter (mid-May $\begin{array}{c}\text { mid-August) pasture residual } \\
(\mathrm{kg} \mathrm{DM} / \mathrm{ha})\end{array}$ \\
\hline 1 & 'SPELL & Spelled (25 May-4 July) \\
2 & 9900 & 900 \\
3 & 1400 & 1400 \\
4 & $' 1800$ & 1800 \\
\hline
\end{tabular}

\section{Management}

Treatments 2,3 and 4 were managed to have $2000 \mathrm{~kg}$ / DM/ha average farm cover at planned start of calving on 15 July, to avoid confounding the effects of winter pasture residual with pasture cover. Rotation lengths of 112, 80 and 40 days in winter achieved the residuals of 900, 1400 and $1800 \mathrm{~kg} \mathrm{DM} /$ ha respectively. Herds 3 and 4 received silage to achieve planned residuals. Cows were re-allocated to herds at calving to avoid confounding the effect of different condition scores resulting from the winter treatments. Herds were balanced for breeding index, age, liveweight (LW), condition score (CS) and calving date. Not all paddocks on treatment 2 had been grazed to $900 \mathrm{~kg} \mathrm{DM} / \mathrm{ha}$ at calving, so these were grazed to that level in early lactation (10.50 kg DM/ha mid July-early August).

Rotation length on all treatments was 80 days on 1 August, 48 days on 1 September and 16 days from 1 October until the end of the experiment, the only exception being the removal of $12.5 \%$ of the farm from grazing from 3 October-19 November on treatment 1 to allow silage conservation.

\section{Measurements}

\section{Animal}

Individual cow milk volume was measured at two consecutive milkings each week. A bulked sample for each cow was analysed for fat and protein content, these two components were used to calculate milksolids (MS) yield. Cows were weighed and scored for condition at fortnightly intervals throughout the experiment. Routine measures of reproduction (calving date, days to 1st oestrus, days to conception, submission rate and conception rate) were recorded or calculated.

\section{Pasture}

Farm cover was assessed at weekly intervals by assigning a visual score to each paddock and converting these to $\mathrm{kg}$ DM/ha based on weekly calibration cuts. Pasture regrowth over a 6 week period was measured on one recently grazed paddock per treatment by cutting four, $0.25 \mathrm{~m}^{2}$ areas on each treatment to ground level at weekly intervals. A new series of measurements started each month on: 12 July, 9 August, 6 September, 4 October, and 1 November. Forty tiller plugs $(5 \mathrm{~cm}$ diameter) per treatment were counted fortnightly for: parent and daughter ryegrass tillers, clover growing points and other grass tillers. In a separate survey 40 tiller plugs per paddock were taken from 8 paddocks per treatment on 12 July and 29 November and counted for: clover growing points, ryegrass, Poa and other grass tillers. Visual assessments of botanical composition were made on each paddock at monthly intervals. Two observers were trained in visual assessment based on botanical dissection of plant material from a range of experiments.

\section{Simulation}

A dairy farm simulation model UDDER (Larcombe 1990) was configured with the results from the actual treatments. It was then used to analyse what might happen at different stocking rates with or without wintering-off. The effect of wintering-off was related to the key parameter of minimum farm cover in September.

\section{Statistical analysis}

Milksolids, LW and CS were analysed by covariance analysis using days since calving as a covariate for 3 periods: 16 July-3 September, 3 September-22 October, and 22 October-15 December. Pasture regrowth was analysed as 2 separate periods: start-week 3, week 3week 6 using ANOVA. Subsamples were used to obtain an estimate of error. Tiller plug data were analysed by ANOVA after square root transformation. Treatment effects on the presence and absence of species in plugs were determined by chi-square analyses.

\section{Results}

\section{Pasture}

The greatest proportionate difference in regrowth in the first 3 weeks after grazing occurred in August: SPELL $>1400>1800>900(\mathrm{P}<0.05)$. Significant effects for other months were not consistent (Table 2). The SPELL treatment produced 49\% more regrowth from week 3-6 for the August closure than the mean of the other three treatments $(\mathrm{P}<0.05)$, but was less than all other treatments for September $(\mathrm{P}<0.05)$. Again, significant effects for other months were inconsistent.

The effect of winter grazing treatment on the proportion of tiller plugs containing either white clover, Poa spp., or perennial ryegrass is shown in Table 3. No treatment effects on any species were apparent in July. By November the SPELL treatment had fewer $(P<0.05)$ plugs containing white clover, and Poa spp. $(\mathrm{P}<0.05)$. 
Table 2 Effect of winter grazing treatment on pasture regrowth ( $\mathrm{kg} \mathrm{DM} / \mathrm{ha}$ ) in weeks (0-3) and weeks (3-6).

\begin{tabular}{|c|c|c|c|c|c|}
\hline \multirow[b]{2}{*}{ Week 0-3 } & \multicolumn{2}{|c|}{ Winter } & \multicolumn{2}{|c|}{ Treatment } & \multirow[b]{2}{*}{ SED } \\
\hline & SPELL, & 900 & 1400 & 1800 & \\
\hline July & 432 & 546 & 241 & 300 & 42 \\
\hline August & 044 & 151 & 577 & 408 & 29 \\
\hline September & 1383 & 1515 & 1397 & 861 & 68 \\
\hline October & 2252 & 2195 & 1785 & 2052 & 68 \\
\hline November & 970 & 589 & 1021 & 964 & 124 \\
\hline \multicolumn{6}{|l|}{ Week 3.6} \\
\hline July & 805 & 940 & 814 & 780 & 49 \\
\hline August & 1632 & 1129 & 1051 & 1107 & 63 \\
\hline September & 172 & 1617 & 1853 & 2189 & 118 \\
\hline October & 1404 & 1303 & 2156 & 3195 & 137 \\
\hline November & 2767 & 3198 & 3816 & 2917 & 185 \\
\hline
\end{tabular}

Table 3 Effect of winter grazing treatment on proportion of tiller plugs containing either white clover, Poa spp., or perennial ryegrass in July and November. (Chisquare test based on all possible species combinations plus absence of all species.)

\begin{tabular}{|c|c|c|c|c|}
\hline & SPELL & 900 & 1400 & 1800 \\
\hline \multicolumn{5}{|c|}{ White clover } \\
\hline July & 81.2 & 70.0 & 80.6 & 70.5 \\
\hline November & 50.3 & 65.0 & 62.6 & 62.8 \\
\hline \multicolumn{5}{|l|}{ Poa spp. } \\
\hline July & 34.4 & 33.7 & 33.7 & 32.5 \\
\hline November & 21.3 & 35.0 & 31.7 & 29.4 \\
\hline \multicolumn{5}{|c|}{ Perennial ryegrass } \\
\hline July & 59.7 & 70.6 & 69.6 & 61.3 \\
\hline November & 63.1 & 71.0 & 68.8 & 70.3 \\
\hline July & $\mathrm{ns}$ & $d f=21$ & & \\
\hline November & $p<0.01$ & $\mathrm{df}=21$ & & \\
\hline
\end{tabular}

There were also fewer plugs with all three species present, and more plugs containing none of the three species $(\mathbf{P}<0.001)$. By November, all treatments had fewer plugs containing white clover than in July, but the proportion of plugs containing perennial ryegrass remained unchanged.

The SPELL treatment had lower perennial ryegrass parent $\left(2740\right.$ vs 4980 tillers $\left./ \mathrm{m}^{2}\right)$ and daughter density (57 vs 214 tillers $\left./ \mathrm{m}^{2}\right)(\mathrm{P}<0.05)$ and white clover density (620 vs 1280 growing points $\left./ \mathrm{m}^{2}\right)(\mathbf{P}<0.001)$ in August than all other treatments. However, these densities increased during spring and by November there were no significant treatment differences. The SPELL treatment contained less clover $(P<0.05)$ than the mean of the other three treatments (11.2 vs 15.5\%) and more dead matter (15.8 vs $7.2 \%)(\mathrm{P}<0.001)$ in July. There was also more dead matter in October (6.8 vs 4.9\%) $(\mathrm{P}<0.001)$. Other winter grazing treatments had no effect on perennial ryegrass, white clover or dead matter content.

\section{Animal}

Table 4 gives treatment effects on milksolids and milk protein yield per cow and liveweight changes. For periods 1 and 2 (16 July-22 October) the only treatment effect was greater milk protein yield in Period 1 for the 1800 compared to the 1400 treatment.

Table 4 The effect of winter grazing management on milksolids and milk protein yield (kglcowlday), liveweight change (kg/cow) and average farm cover ( $\mathrm{kg} \mathrm{DM} / \mathrm{ha})$ for period 1 (16 July-3 September), period 2 (3 September22 October) and period 3 (22 0ctober-15 December). (Least squares means adjusted for days since calving.)

\begin{tabular}{lrrrrr}
\hline & SPELL & 900 & 1400 & 1800 & SED \\
\hline $\begin{array}{lrrrr}\text { Milksolids } \\
\text { Period 1 }\end{array}$ & 1.53 & 1.62 & 1.48 & 1.58 & 0.076 \\
$\begin{array}{l}\text { Period 2 } \\
\text { Period 3 }\end{array}$ & 1.02 & 1.60 & 1.79 & 1.78 & 0.073 \\
Milk Protein & 1.49 & 1.57 & 1.60 & 1.59 & 0.054 \\
Period 1 & & & & & \\
Period 2 & 0.64 & 0.68 & 0.62 & 0.69 & 0.033 \\
Period 3 & 0.60 & 0.78 & 0.79 & 0.78 & 0.033 \\
Liveweight change & 0.62 & 0.67 & 0.69 & 0.66 & 0.025 \\
Period 1 & & & & & \\
Period 2 & -44 & -87 & -66 & -62 & 10.8 \\
Period 3 & -3 & 39 & 30 & 11 & 5.7 \\
Average farm cover & 10 & 16 & 25 & 24 & 6.5 \\
Period 1 & & & & & \\
Period 2 & 2580 & 1910 & 2000 & 1960 & \\
Period 3 & 2820 & 2370 & 2390 & 2360 & \\
\hline
\end{tabular}

In period 3 (22 October-15 December) milk protein yield from the SPELL treatment was less than the 1400 $(\mathrm{P}<0.01), 1800(\mathrm{P}<0.05)$ and $900(\mathrm{P}<0.1)$ treatments. Milksolids yield from the SPELL treatment was less than the 1400 and 1800 treatments $(P<0.1)$. At no stage were significant treatment differences in milk fat yield detected.

Liveweight'losses in period ' 1 are largely due to calving. However, liveweight was regained less quickly for the-900 treatment and was significantly less than thk SPELL treatment $(\mathrm{P}<0.05)$. In period 2 cows on the SPELL treatment continued to lose LW, while those on all other treatments gained $(\mathrm{P}<0.05)$, and in period 3 the SPELL treatment continued to gain less $\mathrm{LW}$ than either the 1400 or $1800(\mathrm{P}<0.05)$.

Days to first oestrus were less on the 1400 treatment (3 1 days) than on the other three treatments (mean $=43$ days) $(\mathrm{P}<0.00 \mathrm{I})$. There were no significant differences in days to conception, submission rate or conception rate. 


\section{Simulation}

Model simulations were run at 3.4-3.9 cows/ha for a 40 day wintering-off period from late May-July and an onfarm wintering system. Both systems were optimised for pasture allocation (rotation length) from JulyNovember. Table-5 shows the advantage to milksolids/ ha from wintering-off compared to on-farm wintering for a range of realistic minimum farm covers. in September. Wintering-off only. produces extra milksolids/ha when on-farm wintering will lead to average farm covers below $1750 \mathrm{~kg} \mathrm{DM} / \mathrm{ha}$ in September. It is not a linear relationship - yield responses become increasingly large as farm cover declines.

Table 5 Effect of minimum farm cover in September on milksolids advantage to wintering-off as simulated by UDDER.

\begin{tabular}{ccc}
\hline $\begin{array}{c}\text { Minimum farm cover }=\text { on farm } \\
\text { wintering (kg DM/ha) }\end{array}$ & $\begin{array}{c}\text { Milksolids advantage to } \\
\text { wintering-off (kg/ha) }\end{array}$ \\
\hline 1400 & 7 & 5 \\
1600 & 25 & -9 \\
1800 & -11 \\
2000 & -13 \\
2200 & \\
\hline
\end{tabular}

\section{Discussion}

$\begin{array}{lllllll}\mathbf{P} & \mathbf{a} & \mathbf{s} & \mathbf{t} & \mathbf{u} & \mathbf{r} & \mathbf{e}\end{array}$

The much greater-regrowth in the first 3 weeks after grazing for the SPELL treatment in August was unexpected. This could not be attributed to differences in grazing residuals because these were the same for all treatments. Brougham's (1956) work indicated that a high pasture mass in late winter as a result of autumnsaved pasture will have a deleterious effect on both pasture quality and subsequent regrowth. This has been attributed to a reduction in tiller and stolon density and lack of available nitrogen. In the present experiment both ryegrass tiller density and white clover growing points decreased in August on the SPELL treatment. However, there is now evidence (Chapman et al. 1983) that tiller density is not a good indicator of total pasture yield. The lack of any treatment differences in either ryegrass or white clover density by November, demonstrate the recuperative ability of these pastures. However, presence and absence data on tiller plugs in November showed that the SPELL treatment had larger areas without white clover, larger areas of bare ground and a reduced distribution of Poa spp. The reduced light environment in the SPELL swards from June onwards may be responsible for lower germination and/ or survival of Poa annua.
The inconsistent treatment effects on regrowth from monthly closures, reinforces the notion that factors other than grazing management determine the total yield of pasture when grazed under feasible systems (Bryant \& Sheath 1987). It implies that a wide range of wintering options can be adopted without concern that subsequent lactation performance will be compromised.

\section{Animal}

The three winter grazing residuals had no effect on total milksolids yield, or on pattern of milksolids production during the spring. This agrees with the similarity in total farm cover at calving and pasture regrowth in the first 3 weeks after grazing. There was no advantage in milksolids/cow to any treatment from calving to 22 October, implying no advantage to the $30-40 \%$ higher pasture allowance, as a result of higher pasture cover, in early lactation for the SPELL treatment.

From 22 October until 15 December the SPELL treatment produced less milksolidslcow than the 1400 and 1800 treatments, and less milk protein than all other treatments. This was probably due to the lower digestibility of the SPELL pasture during this period, resulting. from the higher 'average farm cover carried throughout the spring (Hoogendoorn et al. 1988). With hindsight, silage should have been made a month earlier in mid-October rather than mid-November. Hoogendoom et al. (1988) recommended residual herbage mass of no more than $1500 \mathrm{~kg} \mathrm{DM} / \mathrm{ha}$ throughout spring, if depression of milk yield by decreased pasture quality was to be avoided.- In the present experiment mean September-October residual herbage mass was $1750 \mathrm{~kg}$ DM/ha averaged over the three winter grazed treatments, compared with $2125 \mathrm{~kg} \mathrm{DM} / \mathrm{ha}$ for the SPELL treatment,

The liveweight data (Table 4) show the nutritional profile of cows on the different treatments. From calving to 3 September SPELL cows lost less LW than cows on the 900 treatment indicating better nutritional status post-calving. However, from 3 September onwards the SPELL cows gained only $7 \mathrm{~kg}$ while the average for the other three treatments was $48 \mathrm{~kg}$ - a reflection of the better quality pasture on the latter treatments. No explanation is offered for the much shorter period to first oestrus for cows on the 1400 treatment compared with the rest.

\section{Simulation}

The UDDER simulations predicted that wintering-off becomes a sensible option for increasing milksolids if average farm cover is likely to fall below $1750 \mathrm{~kg} \mathrm{DM} /$ ha in September. Feed budgeting in autumn can help predict the likelihood of this happening. In the present experiment average farm covers in September for the three winter grazing treatments reached minima of 
approximately $1900 \mathrm{~kg}$ DM/ha (Table 4). Simulations suggest that at this level there would be no production advantage to wintering-off.

\section{Implications}

The combined experimental and simulation data suggest that wintering-off will:

- Not lead to serious changes in pasture composition

- Allow more silage to be conserved

- Make the timing and amount of conservation critical if pasture quality is to be maintained in late spring and a decline in milksolids avoided

- Lead to increased milksolids/ha when average farm cover in September will fall below $1750 \mathrm{~kg} \mathrm{DM} / \mathrm{ha}$ if cows are wintered-on.

Provided adequate pasture covers are 'achieved at calving and in early lactation, a wide range of wintering options can be used without affecting the subsequent lactation,

\section{REFERENCES}

Brougham, R.W. 1956. The'rate of growth of shortrotation ryegrass pastures during the late autumn, winter and early spring. NZ journal of science and technology 38A: 78-87.

Bryant, A.M.; Sheath, G.W. 1987. The importance of grazing management to animal production in New
Zealand. Proceedings of the 4th Australasian Animal Science Congress: 13- 17.

Chapman, D.F.; Clark, D.A.; Land, C.A.; Dymock, N. 1983. Leaf and tiller growth of Lolium perenne and Agrostis spp. and leaf appearance rates of Trifolium repens in set-stocked and rotationally grazed hill pastures. NZ journal of agricultural Research 26: 159-168.

Chapman, M. 1994. Research into ryegrass pulling. B.Sc. (Technology) Industry report, University of Waikato, Hamilton, New Zealand (unpublished).

Greenwood, P.B.; McNamara, R.M. 1992. An analysis of the physical condition of two intensively grazed Southland soils. Proceedings of the NZ Grassland Association 54: 7 1-75.

Hoogendoorn, C.J.; Holmes, C.W.; Chu, A.C.P. 1988. Grazing management in spring and subsequent dairy cow performance. Proceedings of the NZ Grassland Association 49: 7-10.

Larcombe, M.T. 1990. UDDER . Operating manual (version 6.3)

Robertson, K. 1994. Focus farm selection. Proceedings of the Taranaki Large Herds Conference, New Plymouth, p.15-21.

Stakelum, G. 1994. New Zealand Dairying from an Irish perspective. Proceedings of the Taranaki Large Herds Conference, New Plymouth, p.77-84. 